\title{
НЕКОТОРЫЕ МЕТОДОЛОГИЧЕСКИЕ ПРОБЛЕМЫ ПОСТСОВЕТСКОГО ПЕРИОДА РОССИЙСКОГО ГОСУДАРСТВА И ПРАВА
}

$(7$

татья посвящена анализу методологических проблем Российского государства и права в переходный период и не нашедших освещения в курсе «Актуальные проблемы государства и права». Содержание статьи определяется следующими обстоятельствами ${ }^{1}$.

Во-первых, на форуме «Россия зовёт!» глава Министерства экономического развития России А. Белоусов признал, что по мере сползания мировой экономики в рецессию и развития энергосберегающих технологий потребление нефти в мире будет сокращаться.

Недовольство самой активной части населения будет расти, переходя из экономической плоскости в политическую.

По оценке А. Белоусова, если до кризиса темпы роста производства энергетических товаров в физическом выражении составлял 6-7\% в год, и это давало России примерно 2,5\% годового роста ВВП, то в перспективе этот фактор превращается в ноль. Более того, «в лучшем случае в ноль. Он может стать и отрицательным. То есть, из драйвера роста энергетический сектор может превратиться в тормоз».

По сути, речь идёт о размежевании элиты. Одна её часть считает, что в политике ничего менять не стоит. Что природных ресурсов хватит на многие десятилетия и «торопиться не надо». А тем, кто возбуждает

\footnotetext{
1 Научный доклад на заседания секции УМО «Предпринимательское право» и круглого стола на тему: «Реализация целей правовой политики в системе образования и предпринимательства» в рамках Второй московской юридической недели Москва (27 ноября 2012 г.) на XIII международной научно-практической конференции «Правовая политика: вызовы современности» В Московском государственном университете имени М.В. Ломоносова.
}

недовольство, нужно укоротить языки. Если цены на сырьё будут падать, говорят они, — запросы среднего класса, ориентирующегося на европейское качество жизни, удовлетворять будет всё труднее.

Во-вторых, в вышедшей в свет монографии «Национальная идея России», где на основе мультидисциплинарного научного подхода, логико-философского и математического моделирования успешности страны, в качестве показателя ее жизнеспособности, проанализирована специфика России как цивилизации, как государства, как страны, как человеческого сообщества. В монографии показана связь качества конкретного многофакторного государственного управления, общественной активности и успешности страны в целом. Выявлены специфические ключи к успеху России, отличающиеся от таковых для иных государств-цивилизаций. В монографии показано, что современная социально-экономическая и политическая модель страны мало совместима с жизнеспособностью России ${ }^{2}$.

2 Национальная идея России: в 6 т. - М.: Научный эксперт, 2012. В исследованиях и написании монографии приняли участие: В.В. Аверков, И.Р. Ахметзянова, В.Э. Багдасарян, А.Р. Бахтизин, И.И. Белобородов, П.Г. Белов, Е.Э. Буянова, Д.А. Васюкова, Д.Д. Венедиктов, М.В. Вилисов, О.Д. Воробьева, М.В. Глигич-Золотарева, И.А. Гундаров, Т.А. Данилина, М.В. Деева, С.В. Дерин, А.В. Дмитриев, Д.А. Журавлев, С.Г. Кара-Мурза, Г.Г. Каримова, А.Э. Клейнхоф, Н.Н. Клюев, И.Ю. Колесник, А.В. Кондаков, Е.А. Куренкова, О.В. Куропаткина, В.Н. Лексин, О.Г. Леонова, И.А. Липский, Л.А. Макурина, С.Ю. Малков, А.С. Малчинов, В.Л. Манько, А.Н. Маслова, И.В. Метлик, М.М. Мчедлова, М.С. Нетесова, И.Б. Орлов, С.Ю. Пантелеев, А.И. Петренко, М.Ю. Погорелко, И.В. Репин, Е.С. Сазонова, Ю.А. Сафонова, К.В. Сивков, В.В. Симонов, Ю.И. Скуратов, В.С. Смирнов, С.М. Строганова, С.С. Сулакшин, И.Ю. Сундиев, А.В. Тимченко, Д.Б. Фролов, А.И. Фурсов. 
C учетом указанных факторов, в статье рассмотрены следующие проблемы: о необходимости смены сырьевой модели развития, во - вторых - о разработки идеологии развития страны, в — третьих — pacсмотрение теоретических вопросов второго этапа кодификации российского законодательства.

\section{I. О необходимости смены сырьевой модели развития}

Основные черты феодально-олигархической модели «экономики трубы». Пореформенная модель хозяйства не может более удовлетворять ни один из слоев российского общества, включая действующую власть, тем более, общество в целом.

На форуме «Россия зовёт!», глава Министерства экономического развития России А. Белоусов, официально озвучил то, о чём уже многие годы, говорят лучшие российские макроэкономисты: модель паразитического проедания природной ренты и хищнической эксплуатации научно-технического и производственного потенциала, доставшегося в наследство от СССР, себя исчерпала.

Сегодня объёмы выпуска наукоёмкой продукции в 3-10 раз ниже, чем 20 лет назад, объём капитальных вложений в высокотехнологичные производства находится на отметке середины 1960-х гг. (35\% от 1990г.), а износ базовой технологической инфраструктуры зашкаливает за $80-85 \%$.

В силу занимаемой позиции в вертикали власти Белоусов не стал озвучивать вслух цену президентским обещаниям по удвоению ВВП и говорить о том, какой ценой и за счёт чего удалось продемонстрировать весь рост российской деиндустриализированной «экономики трубы» в период 2002-11 гг.

По сути дела, то, что в научном сообществе именуется структурной деградацией экономики, разрушением научно-технического потенциала, качественной примитивизацией производства и превращением в «сырьевую колонию» преподносилось российскими властями и контролируемыми ими СМИ в качестве «вставания с колен», выхода из упадка 90-х и бурного развития отечественной экономики ${ }^{3}$. базируется на сверхэксплуатации природных и человеческих ресурсов нашей страны, а потому не в состоянии создавать что-то новое и продуктивное, являясь тупиковой ветвью экономического бытия. Модернизировать здесь просто нечего - нет ни субъекта, ни объекта модернизации.

См.: Жуковский В. «Вылетаем в трубу»/ Завтра. 2012. - № 44.
От пореформенной модели российского хозяйства нам нужно переходить к постреформенной. Модернизировать, «улучшать» пореформенную модель , означает только еще дальше залезать в социально-экономический тупик. Сырьевая колония и свалка для отходов мирового производства - вот будущее России в рамках действующей модели хозяйства. Разумеется, можно жить и в колонии, можно жить и на свалке, но история и потенциал нашей страны таковы, что подобное будущее вряд ли кого-то способно устроить 4 .

Идеологическое обоснование «экономики трубы». Указанное положение вещей сложилось в результате использования правящем класса идеология «Вашингтонского консенсуса». Идеология «Вашингтонского консенсуса» отличается кратким упрощением задач экономической политики и сведение её к трём постулатам: либерализация, приватизация и стабилизация через жёсткое формальное планирование денежной массы.

В 1989 г. такая модель экономического развития была оформлена в виде идеологической доктрины под названием «Вашингтонский консенсус». Автор этого выражения, Джон Вильямсон, экономист Института международной экономики в Вашингтоне, включал в эту доктрину макроэкономическую стабилизацию, микроэкономическую либерализацию и открытие внутреннего рынка для иностранных инвестиций и свободного перемещения капиталов.

Но после десятилетнего «опыта» внедрения «вашингтонского консенсуса» по всему миру бывший главный экономист программы ООН по вопросам развития Изабелл Грюнберг сформулировала его принципы 5 .

В 1992 г. Россия вступила в Международный валютный фонд (МВФ), и правительство Ельцина- Гайдара подписало с фондом « Письмо о намерениях», взяв обязательства внедрять программы «переходного периода», законы и кодексы, разработанные только экспертами фонда. Таким образом, формирование институтов «рыночной экономики» перешло к МВФ, представляющему интересы США и ЕС. В Конституцию РФ 1993 г. включено положение (ст. 15.п. 4): «Если международным договором РФ установлены иные правила, чем предусмотренные законом, то применяются правила международного договора» .

Поэтому Президент и Правительство России являются в рамках международного договора - «Письма о намерениях» только исполнителями программ «переходного периода», менеджерами, выбранными субъек-

4 См.: Примаков Е.М. Достижения не должны заслонять проблемы // Российская газета. 2011. - 14 января.

5 См.: Глазьев С.Ю. Родина в опасности. - М., 2009. - С. 7. 
СТРУКТУРА ЭКОНОМИКИ РЯДА СТРАН МИРА,

В ПОСТОЯННЫХ ЦЕНАХ, (B \% К ВВП)

\begin{tabular}{|c|c|c|c|c|c|}
\hline Страна & $\begin{array}{c}0 б \text { ра баты ва } \\
\text { ющая про } \\
\text { мыш лен } \\
\text { ность }\end{array}$ & $\begin{array}{c}\text { Добывающая } \\
\text { промышлен- } \\
\text { ность }\end{array}$ & $\begin{array}{c}\text { Внутренняя } \\
\text { торговля }\end{array}$ & $\begin{array}{c}\text { Фн нан со вый } \\
\text { сек тор, вклю- } \\
\text { чая опе ра ции } \\
\text { с нед ви жи } \\
\text { мостью }\end{array}$ & $\begin{array}{c}\text { Здра во ох ра } \\
\text { не ние, об ра } \\
30 \text { ванне, со } \\
\text { ци аль ные ус } \\
\text { луги }\end{array}$ \\
\hline США & 15,4 & 0,9 & 16,8 & 33,2 & 14,6 \\
\hline Канада & 15,0 & 5,2 & 14,6 & 26,5 & 13,9 \\
\hline Норвегия & 10,7 & 8,8 & 17,2 & 18,4 & 13,6 \\
\hline Австралия & 9,8 & 7,6 & 12,8 & 29,5 & 14,4 \\
\hline Индия & 14,5 & 1,8 & 14,7 & 13,7 & 7,4 \\
\hline Еразилия & 15,1 & 2,1 & 18,7 & 16,3 & 11,6 \\
\hline ЮAP & 15,9 & 5,0 & 13,8 & 22,0 & 3,4 \\
\hline Китай & 32,8 & 5,6 & 9,4 & 9,5 & 15,3 \\
\hline Россия & 14,1 & 5,7 & 27,0 & 16,7 & 6,5 \\
\hline
\end{tabular}

том управления. Ежегодно МВФ в соответствии с договором оценивает результаты реализации программ за прошедший год, доводит правительству РФ задания по их исполнению на предстоящий год, устанавливает параметры бюджета, величину Стабфонда и отчислений из бюджета для погашения госдолга, процент инфляции. Правительство РФ с учетом указаний формирует проект бюджета, передает его на рассмотрение Федеральному Собранию, на подпись президенту Р $\Phi^{61}$.

В результате применения идеологии «Вашингтонского консенсуса» в России сложилась парадоксальная ситуация, суть которой определяется формулировкой: «Не Минфин при правительстве, а правительство при Минфине». Говоря простым языком, это означает, что Президент и глава правительства в предвыборной эйфории могут заявлять, что угодно и раздавать какие угодно обещания относительно модернизации экономики, сокращения чудовищной имущественной пропасти и т.д. Однако ключевые решения в области разработки и реализации приоритетов социально-экономической политики и общий вектор движения определяют вовсе не они, а Минфин.

Какой в России капитализм. В настоящее время в России в основном сформировалась капиталистическая система. Однако, как не стремились ее создатели

\footnotetext{
6 См.: Дойников И.В. Национальное доктрина хозяйствования и современная либеральная теория гражданского и предпринимательского права // Бизнес в законе. Экономикоправовой журнал. - 2007. - № 3. - С. 168.
}

копировать капиталистические страны Запада, как не усердствовали они, выполняя указания Международного Валютного Фонда, в силу специфических условий современный российский капитализм существенно отличается от своих западных собратьев.

Во-первых, российский капитализм - капитализм непроизводительный, торгово-ростовщический. Основной источник доходов новоявленных российских капиталистов - не прибыль от производственной деятельности, а доход от коммерческих и финансовых спекуляций. Поэтому господствующей формой эксплуатации трудящихся в современной России является непромышленная эксплуатация, описанная Марксом, а более изощренная и завуалированная торговоростовщическая эксплуатация с помощью механизма цен, кредита, финансовых махинаций.

Во-вторых, российский капитализм - капитализм олигархический. Основная часть богатства страны и соответственно основная масса доходов попала в руки кучек крупнейших финансовых воротил. Именно они стали сегодня реальными хозяевами страны, в их интересах проводится внутренняя и внешняя политика России.

В-третьих, российский капитализм - капитализм криминальный. Значительная часть народного богатства находится под контролем криминальных и полукриминальных структур, которые все более интенсивно сращиваются с государственным аппаратом и оказывают активное воздействие на все стороны общественной жизни. 
B-четвертых. российский капитализм - капитализм компрадорский. Экономика все в большей мере попадает в прямую или косвенную зависимость от иностранного капитала и функционирует в интеpecax крупных империалистических государств и транснациональных корпораций. Существующая в стране так называемая «патриотических - ориентированная» буржуазия состоит в основном из тех кому пока не удалось выгодно продаться иностранному капиталу?

По просьбе академика РАН Е.Примакова, Институт мировой экономики и международных отношений Российской академии наук подготовил таблицу «Структура экономики ряда стран в постоянных ценах (в процентах к ВВП)». Данные за 2008 год и в ценах 2003 года. Поскольку структура ВВП меняется очень медленно, можно с большой долей вероятности считать, что это современная структура ${ }^{8} .1111$

Проблемы ошибочности экономического управления России. По мнению авторов шеститомной монографии «Национальная идея России», самый очевидный вывод, - это то, что обвал жизнеспособности страны в 1990-е гг. совпадает с резким ростом ошибочности управления. Такого уровня ошибочности управления в истории России не наблюдалось никогда. Поэтому возможно, что мы имели дело не с ошибочностью управления, а с очень продуманным и навязанным стране «антипроектом», цель которого вовсе не развитие России 9 .

Описанная ситуация теоретически может иметь место только в трех случаях:

1. Управление ошибочно ввиду непрофессионализма управленцев;

2. Управление преследует иные, нежели развитие страны, цели (чаще всего это случай сверхкоррупции);

3. Управление носит диверсионный характер, т.е. осуществляется в интересах иных государств.

Успешность экономического развития зависит от качества государственного управления в этой сфере и определяется следующими параметрами: монетизация экономики; доля государственных расходов в ВВП; доля оплаты труда в ВВП; внешнеторговый оборот; отношение экспорта к импорту; доля государственного бюджета, направляемая на оборону, науку, здравоохранение,

\footnotetext{
7 Путь в XXI век: стратегические проблемы и перспективы российской экономики / Рук. акад. Д.С. Львов - М., 1999; Стратегический ответ России на вызов нового времени / Под ред. акад. Л.И. Абалкина - М., 2004; Меньшиков С. Анатомия российского капитализма. - М., 2004.

8 См.: Примаков Е.М. Статистика ООН // Российская газета. $-2012 .-9$ июня.

9 См.: Национальная идея России. Т. 4. - М., 2012. - С. 2262.
}

культуру, образование, субсидирование сельского хозяйства; соотношение платного и бюджетного образования; доля населения, занятого в силовых структурах и армии; соотношение доходов федерального бюджета и бюджетов регионов; соотношение расходов федерального бюджета и бюджетов регионов.

В исторической динамике ошибочности экономического управления интересно отметить мобилизующую роль мировых войн, эффект смены экономической системы после 1917 г. и эффект «сталинского ренессанса» 1935 г., отчасти приоткрывающий завесу над причинами репрессивных действий власти в те времена. Видны растерянность в экономическом управлении во время борьбы за власть после смерти Сталина.

Четко просматривается период хрущевского волюнтаризма, закончившийся с приходом Брежнева. Постепенный выход на более эффективное экономическое управление вплоть до 1985 г., когда началась горбачевская перестройка.

Здесь наблюдается скачок нелепости в экономическом управлении, затем такой же резкий скачок в 1991 г., с началом «рыночной» реформы по Гайдару.

Эффективность управления увеличивалась по мере адаптации к новым условиям, а минимальной ошибочность была в короткий период правительства Примакова.

Приход В. Путина и его команды вновь ознаменовался резким скачком ошибочности управления. История показывает, насколько неустойчива модель управления в России до сих пор. Естественным является то, что ошибочность экономического управления является фактором снижения жизнеспособности страны.

Анализ факторного пространства экономического развития, по мнению авторов шеститомной монографии «Национальная идея России», как сферы одного из главных факторов-потенциалов жизнеспособности страны, выявляет следующие основные проблемы, требующие своего решения.

1. Главная проблема - это приверженность государственного управления догматике экстремального либерализма. Вместо оптимизации регулирующих государственных функций реализуется их элиминация. По этой причине доля государственных расходов в ВВП, доля государственного имущества в структуре собственности страны далеки от оптимальных и меняются в неоптимальном направлении.

2. Системы мотивации труда, организации производства, иные экономические условия не учитывают цивилизационные особенности России, что не позволяет достигать оптимальных состояний производства и потребления. 
3. Монетаристская модель национальной финансовой системы. Уровень монетизации необоснованно занижен в 3-7 раз. Центральный банк осуществляет весьма подавленную эмиссию исключительно под потребности сырьевого экспорта и вне связи с потребностями экономического развития страны и обеспечения ликвидности банковской системы.

4. Системно выстраиваемый сырьевой и низкопередельный тип российской экономической модели. Структура выпуска и структура инвестиций по видам экономической деятельности государством не управляется, что еще более закрепляет выбор сырьевой модели.

5. Избыточно экспортизированный тип экономики. Из страны вывозится ресурсов до трех раз больше, чем ввозится. Валютная выручка также в основном из страны экспортируется.

6. Не происходит равномерность управления развития регионов, а нарастают их диспропорции.

7. Не управляется распределение доходов населения. Выведены из-под мониторинга и фактически изпод адекватного налогообложения наиболее высокодоходные группы. Расслоение населения по доходам нарастает. Сокращения бедности в должной мере не происходит.

8. Заниженный в 2-2,5 раза уровень оплаты труда демотивирует производительность труда, не обеспечивает воспроизводства человеческого капитала и порождает демографическую деградацию, лишает банковский депозитно-кредитный механизм средств населения и делает проблему адекватного пенсионного обеспечения неразрешимой. В результате происходит последовательная деградация человеческого капитала.

9. Основные ресурсы экономического развития инвестиции и оборотные финансовые средства - заметно подавлены в результате проведения в жизнь политики монетаризма, что тормозит развитие экономики страны.

\section{II. Идеология развития}

Направления в обществоведении России. В обществоведении России за два десятилетия «реформ» выкристаллизовалось два направления, Первое официальное (основанное на западных либеральных догмах Гайдара, Чубайса, Кудрина, Мау, Ясина и прочих младореформаторов), оправдывающее существование откровенно паразитической феодально-олигархической модели «экономики трубы».

В современном обществоведении получила развитие обозначенная еще в Беловежье «линия», со- гласно которой распад Союза ССР закономерен и объективен. А.Н. Сахаров успокаивал сограждан: «Происходит то, что и должно происходить... Россия просто проходит со значительным запозданием те же цивилизационные ступени эволюции, что и другие развитые страны. Дескать, цивилизационное развитие и политическая жизнь 60-70-х гг. практически подготовили распад Союза, и тут уж ничего не поделаешь. Согласно такому подходу, СССР, как и советский социальный строй, рухнул в силу своей внутренней несостоятельности, он изжил себя сам по себе, будто советские люди сами (на своем жизненном опыте) пришли к мысли о необходимости отказа и от своего «имперского» государства, и от социализма; СССР саморазрушился».

Директор Института всеобщей истории РАН Чубарьян А.О представляет распад СССР результатом «с одной стороны, роста национального самосознания, с другой - краха тех методов, с помощью которых создавался и жил СССР». Со ссылками на общецивилизационные основы выстраиваются объяснения крушения СССР его проигрышем в холодной войне в результате технологического отставания и снижения уровня конкурентности, поражением социализма в многовековом соперничестве с либерализмом .

В соответствии с таким подходом распад СССР объясняется «порочностью, авантюристичностью самой идеи социализма в ее марксистском варианте», и роспуск СССР предстает уже как счастливый случай избавления от «насквозь прогнившего имперского альянса», или как некая спасительная превентивная мера, предупредившая еще большее несчастье «полномасштабную национально-освободительную (или имперско-восстановительную) резню». В ряде случаев вина за распад СССР перекладывается на других носителей власти в бывшем СССР - гекачепистов; депутатов V Внеочередного съезда народных депутатов СССР, во многом предопределивших своими решениями разрушение Союза.

Второе направление - это национально - ориентированное обществоведение, пытающееся в условиях либерального идеологического террора осмыслить, то, что произошло с обществом и государством, за последние двадцать лет.

Методологические основы научного осмысления, произошедшего с обществом и государством, за последние двадцать лет заложили труды ученых национальногосударственной ориентации. В сфере философии — это работы А. Зиновьева, С. Гончарука, А. Дугина и др., в сфере социологии и истории - А. Барсенкова, А. Вдовина, Ю. Жукова, В. Семенова, В. Соловей, С. Валян- 
ского и Д. Калюжного, в политологии - А. Панарина, Л. Ивашова, С. Кара-Мурзы и др., в сфере экономики - Л. Абалкина, С. Глазьева, Д. Львова, А. Некипелова, О. Богомолова и др.

Научной основой разработки теории выхода из системного кризиса страны служат идейно - теоретические взгляды политических партий, ориентирующихся на доктрину социализма XXI в., как представленных в Государственной Думе РФ, так и не имеющих пока этого представительства.

Изгнанный из СССР и проживший долго за рубежом известный философ и писатель Александр Зиновьев пришёл к выводу, что западные люди подвергаются неизмеримо большему идеологическому оболваниванию, чем советские, хотя и не замечают этого. Теперь Россия может дать фору Западу.

Идеология потребительского общества. В период антисоциалистической контрреволюции 1990-х свобода и демократия связывались с полной ликвидацией основ прежнего общества и его надстройки.

Мировоззрение правящего в России класса, по своей природе почти полностью сформировавшегося на освоении государственной собственности и демонтаже державы. В силу существовавших обстоятельств, представители правящего класса научились богатеть за счет страны, но не вместе с ней Господствующая у нас идеология нацелена на закрепление и освящение власти денежного мешка. В результате стирается грань между свободой и вседозволенности.

Характеризуя статус-кво, либералы предпочитают говорить о «засилье бюрократии», призывают государство «уйти из экономики». Но отрицать факт доминирования олигархического капитала и его срастания с верхушкой коррумпированного чиновничества невозможно.

Вместо общественного блага либералы провозгласили культ личного интереса с девизом: «Обогащайся!» Выпестованная властями «семибанкирщина» знала приписываемую Черчиллю формулу: «Кто владеет информацией - тот владеет миром». Во всяком случае, она тотчас же потянулась к СМИ. Стоит ли удивляться, что оказавшиеся в руках олигархов СМИ насаждают идеологию потребительского общества, телеканалы потчуют нас бандитскими детективами, низкопробной развлекаловкой и чернухой, а пресса столь основательно пожелтела? Мозги граждан как будто целенаправленно замусоривают, а мысли отвлекают от острых социальных вопросов ${ }^{10}$.

Экономика генерирования прибыли. Восторжествовавший неолиберализм, а затем вызванный им

10 См.: Цаголов Г. Заставить делиться // Литературная газета. - 2012. - № 39 . кризис превратили пропагандируемый и всеми средствами превозносимый рынок на деле лишь в косвенный ориентир, разрегулировав и придав экономическим процессам стихийный характер, в значительной мере девальвировав этические нормы ведения бизнеса. Погоня за прибылью, борьба за успех и просто за выживание отодвинули на второй план все остальное. И законы, и мораль. Ситуация с выраженной и завуалированной экономической преступной деятельностью обострилась по всему миру. Так, например, по оценкам Национального центра исследований мошенничества США, если в 1970 г. экономические преступления обошлись стране в 5 млрд. долларов, в 1980 г. — 20 млрд. в 1990 г. -100 млрд, то сегодня только прямые убытки от действий корпоративных преступников обходятся в 200 млрд. долларов в год (оценка профессора Стива Альбрехта из Университета Бригама Янга). Во Франции общий ущерб от экономических преступлений еще в конце прошлого тысячелетия вдвое превзошел совокупный бюджет МВД, юстиции и здравоохранения ${ }^{11}$.

Из России изначально пытались всеми силами сделать и сделали помойку для сбыта контрафакта и всевозможных залежалых и некачественных товаров, от которых цивилизованные народы воротят нос. Правительство, к примеру, той же Турции, недавно осуществившей, по сути, пиратский акт по изъятию российской продукции двойного назначения, предназначавшейся Сирии и не запрещенной никакими международными документами, закрывает глаза на целую индустрию контрафакта, работающую на ее территории и поставляющую свои изделия главным образом в нашу страну. Практически легально здесь производится все - от ювелирных изделий из низкопробного золота или вообще без такового и до продуктов питания, элитного алкоголя, всевозможных «дорогих» меховых изделий и аксессуаров. Причем клейма и брендовые лейблы на указанные подделки поставят любые, как российские (например, ведущих отечественных ювелирных заводов), так и мировые (Gucci, Prada, Trussardi, Nina Ricci, Cavalli, Chanel, Wrangler - пожалуйста). Недалеко ушли в этом отношении и другие страны.

Но контрафакт и теневой рынок - это лишь часть проблемы. Причем не самая большая и не самая глав-

1122 октября 2012 г. в рамках международного форума «Антиконтрафакт-2012», по сообщениюИА «Росбалт»в Москве прошел первый международный форум «Антиконтрафакт», на котором представители бизнеса, Минпромторга и МВД, насколько это возможно, сообща пытались разобраться, как остановить лавину подделок - от DVD-дисков до лекарств, в буквальном смысле накрывшую собой Россию. 
ная. Проблемы, суть которой заключается в постепенном и незаметном большинству обывателей стирании граней между преследуемой по закону экономической преступной деятельностью и латентной (но преступной по самой сути) деятельностью корпораций, финансовых империй, людей, обличенных богатством и властью, чьи деяния несут государствам и народам не меньший, а больший вред, но к ответу за это не привлекаются ${ }^{12}$.

«Величайшие преступления совершаются из-за стремления к избытку, а не к предметам первой необходимости». Эти слова Аристотеля, если можно так выразиться, и сегодня живее всех живых.

В современных условиях господства неолиберальных принципов и ценностей они звучат актуально как никогда. Поскольку то, что американский экономист и основоположник институционального направления в политической экономии Торстейн Веблен называл «хищнической фазой» человеческого развития, приобретя лощеный, «цивилизованный» вид, в плане результативности своей разрушительной и вредоносной деятельности стало гораздо более эффективным.

Главные герои этой деятельности отнюдь не громилы и кровавые маньяки с бензопилами, а вполне респектабельные и уважаемые в построенном ими мире люди. В основе этого мира лежит трансформированная модель капитализма, главным движущим фактором которой в отличие от старого производственного капитализма является не товарность, а прибыльность. То есть прибыль любой ценой, независимо от того, что несет увеличение этой прибыльности государству, остальным членам общества, окружающей среде, будущему. Это первое.

Второе. Всем многообразием самых современных и качественных товаров и услуг сможет в полной мере пользоваться и владеть, как, собственно, и наслаждаться всеми благами жизни, на которые способен прогресс текущего момента, только та часть общества, которая в состоянии генерировать эту прибыль. Не производить что-то, а именно генерировать прибыль. Одно, конечно, другому не мешает, но производство при этом осуществляется в целях прибыли, а не потребления. Отсюда все глобальные изменения свойств и качества товаров и услуг, которые мы наблюдаем в последние десятилетия.

Генно-модифицированные сельхозпродукты, изделия пищевой промышленности, больше напоминающие нетленные мумии и «живую воду», товары массо-

12 См.: Бондарь В. Этот преступный, преступный, преступный мир // Однако. - 2012. - № 33. - С. 42. вого спроса, напротив, преднамеренно рассчитанные на минимальные сроки использования, кредитные финансовые инструменты, изначально и опять же преднамеренно лишенные гарантированной материальной опорной основы, - все это придумано не просто так, а для того, чтобы за счет одурачиваемого массового потребителя избранная группа генераторов прибыли получала ее в геометрической прогрессии, независимо ни от чего ${ }^{13}$.

Выбор пути развития. «Россия потеряла сюжет своего существования... Если граждане страны не улавливают сюжет существования государства - оно разваливается», - не без горечи констатирует проницательный Фазиль Искандер, - К чему стремимся?». Поиск общенациональных целей и интегральной идеологии нельзя вести без уяснения того, в каком обществе мы живём и к чему следует стремиться. Открывший дискуссию на обсуждаемую тему профессор Б.Ф. Славин прав в том, что с самого начала надлежит уточнить «образ будущего общества, более совершенного, чем то, которое в данный момент существует в реальности».

В дискуссиях, по мнению Г. Цаголова, обозначились три позиции:

1) «нормальный» капитализм;

2) социализм прежнего или обновлённого типа;

3) смешанную, или конвергентную модель.

Третья позиция, по мнению Г. Цаголова, заслуживает особого внимания. Комбинируя преимущества капитализма и социализма и отсекая по возможности их недостатки, общество становится устойчивым и динамичным. Гипотезу об успехе конвергенции двух противоположных систем впервые высказал выдворенный из России и оказавшийся впоследствии в Гарварде выдающийся русский социолог Питирим Александрович Сорокин. «Западные лидеры, - писал он в 1960 г., - уверяют нас, что будущее принадлежит капиталистическому типу общества и культуры. Наоборот, лидеры коммунистических наций ожидают победы коммунистов в ближайшее десятилетие. Будучи несогласным с обоими этими предсказаниями, я склонен считать, что... господствующим типом возникающего общества и культуры, вероятно, будет не капиталистический и не коммунистический, а тип специфический, который мы можем обозначить как интегральный» ${ }^{14}$.

13 См.: Бондарь В. Этот преступный, преступный, преступный мир // Однако. 2012. - № 33. - С. 44.

14 См.: Цаголов Г. Заставить делиться // Литературная газета. - 2012. - № 39. 


\section{III. Второй этап кодификации российского законодательства}

Первый этап кодификации российского законодательства постсоветской России связан с экономической реформой, проведенной в начале 90-х годов, и последовавшей за ней кодификацией российского законодательства, привели к системному кризису в обществе. Либеральные «реформаторы» ставили цель перехода к рыночной экономики, но получили в результате - неофеодализм. Замена «плохого» социализма постиндустриальным обществом обернулась в реальности деиндустриализацией и деградацией Российского общества (экономической, социальной и духовной сфер).

Коренной ломке подверглись без какого - либо исключения все отрасли законодательства (были приняты в соответствии с либерально-западной доктриной Вашингтонского консенсуса Гражданский кодекс, Уголовный кодекс, Земельный кодекс, Налоговый кодекс, Трудовой кодексы и другие законы). Политико-правовую доктрину первого этапа кодификации российского законодательства составили идеи либерального фундаментализма.

Основные итоги первого этапа кодификации российского законодательства постсоветской России, во-первых, завершился процесс создания кодифицированных актов по основным отраслям российского права. Во-вторых, была создана иерархическая противоречивая система нормативно-правовых актов, не способная сформировать в стране публичный правопорядок. В-третьих, в новых исторических условиях законодательство «девяностых и двухтысячных» оказалось «заимствованным наростом», тормозящим социально-экономическое развитие страны. В - четвертых, в рамках юридической науки не сложилась современная национальная юридическая школа, базирующаяся на решении экономических, политических, социально-культурных задач, стоящих перед российским обществом. Начался процесс деградации права. В-пятых, юридическая наука, как и обществоведение утратило национальный характер.

Задача второго этапа кодификации российского права - переосмысление либерально-западного научного багажа, преодоление растерянности и преклонения перед западной юридической наукой, развитие идей национальной философии хозяйствования, проведение исследований актуальных народнохозяйственных проблем с учетом принципа экономической безопасности, формирование новых научных направлений на основе национально-государственного подхода, и обеспечения в стране экономического публичного правопорядка.
Методологический подход к проектированию научного макета новой Конституции России. «Модель страны», «успешность страны», по мнению авторов шеститомной монографии «Национальная идея России», вводятся как базовые категории в научно формализованном пространстве функций цели и множества независимых параметров государственного управления, управленческого выбора ${ }^{15}$. В монографии установлена связь Основного закона (Конституции) России, программирующего развитие страны, с реальными ее достижениями и вызовами. По результатам исследования предложены научный макет новой Конституции России, Доктрина безопасности и развития России и производная от этих базовых документов система нормативно-правовых актов, институциональных, социально-экономических, региональных, финансовых, внешнеполитических и гуманитарных принципов жизнеустройства России.

У государства в широком смысле, по мнению авторов шеститомной монографии Национальная идея России, есть неотъемлемые функции или миссия. Это безопасность и устойчивость развития, включая демографическое, мировоззренческая осмысленность жизни и уровень благосостояния ее населения, народосбережение, занятость, здоровье, психологический комфорт, уверенность в будущем. И эти функции далеки от установок государства «сервисного типа».

Оценка правовой доктрины начала 90-х годов. В действующей Конституции РФ, по мнению авторов шеститомной монографии «Национальная идея России», определены высшие ценности - это права и свободы человека и гражданина. Нравственность, справедливость, даже само существование России к высшим ценностям не отнесены ${ }^{16}$.

Такой методологический подход связан с неолиберальной космополитической доктриной, навязанной стране сразу после гражданского конфликта 1993 г., после выстрелов танков по «Белому дому». Определенную примиряющую роль в тот период сыграло принятие Конституции РФ.

Но спустя 20 лет, т.е. после очень длительного периода времени для исторических экспериментов, перед лицом надвигающихся новых угроз для существования российской государственности пришло время переосмыслить важные обстоятельства и реалии обустройства жизни страны.

Никаких иных значимых ценностей, кроме прав и свобод человека и гражданина, в Конституции РФ нет. Права и свободы при этом не увязываются с обязанно-

15 См.: Национальная идея России. - М., 2012. Т. 6. - С. 4021.

16 Национальная идея России. - М., 2012. Т. 6. - С. 4021. 
стями и ответственностью. Государству же не предписано никакой ответственности, а также обязанностей, за исключением признания и соблюдения прав и свобод человека и гражданина.

У страны не определены цели и ценностей развития. В какую сторону она движется и куда должна прийти? Что должно объединять народ и подвигать его на свершения? Ответов в Конституции нет.

Неолиберальная риторика, в поле которой построена Конституция РФ 1993 г., указывает только на «конкурентоспособность страны». Как будто страна — это коммерческая организация, которая на каких-то рынках с кем-то конкурирует.

Так, Конституция РФ запретила идеологию страны. А идеология включает в себя ценности, избранные обществом. Общество и страна без ценностей? Разве может такая страна быть успешной?

Конституция РФ игнорирует цивилизационную специфику русской (российской) цивилизации. Она прямо отрицает российскую государственность времен Советского Союза. Слово «русский» в ней употреблено только один раз (и только по отношению к языку). Но каждая цивилизация успешна только тогда, когда она настроена на свой собственный уникальный рецепт успеха. Чужие рецепты тут беспомощны и даже вредны. Русского народа по Конституции РФ вообще не существует. Государственных (!) языков, помимо русского, в ней установлено множество ( Имеются в виду государственные языки республик - субъектов РФ (ст. 68 Конституции РФ).

Конституция РФ нацелена на единственный безусловный интерес - богатого меньшинства, поэтому имеют место безудержная приватизация, вывоз капиталов из страны, сырьевизация и архаизация экономики, фальсификация продуктов питания и лекарств, коммерциализация социальной и гуманитарной сфер.

Интерес частного (и прежде всего иностранного) капитала торжествует над национальными интересами страны и ее народа. Все: от образования и здравоохранения до деятельности Центрального банка РФ, устраивается на коммерческий лад, идет на продажу, начиная с земли и активов и заканчивая «услугами государства» и ставкой рефинансирования. Государство превращается в сервисное (т.е. предоставляющее услуги за плату), а не жизнеобустраивающее.

Многое из того, что сегодня делает страну неуспешной, запрограммировано в Конституции РФ 1993 г. Чтобы конституция не обслуживала интересы только богатого меньшинства и иностранных государств, а служила собственной стране и ее народу, она должна быть сориентирована на успех страны и ее народа. Это требование порождает специальный ал- горитм построения конституции, который гарантирует, что она будет работать во имя поставленных перед ней целей. Алгоритм в настоящей работе разработан на основании логико-философской и математической теорий успешности сложной социальной системы.

Конституционное законодательство выступает не целью, а средством, инструментарием реализации соответствующих ценностных установок.

Поэтому догматизация текста конституции снижает ее действенные потенциалы. Несоответствие вызовам и запросам современности делает любой закон юридически бессмысленным. Ссылки на историческую устойчивость американской Конституции при этом не всегда оправданны, поскольку она является исключением среди конституций иных иностранных государств.

Как правило, конституционное законодательство довольно часто модернизируется. Из всех существующих в мире конституций $38 \%$ были приняты или существенно модернизированы уже после того, как 12 декабря 1993 г. референдум в России утвердил новую Конституцию.

«Возрастное» распределение конституций зарубежных стран позволяет заметить, что российская не выглядит в достаточной степени «молодой».

Конституционно-правовые основы жизненно важных параметров развития страны. Радикализация конституционной неолиберальной космополитической доктрины в последнее время явно ориентирует страну на движение к кризису и, возможно, распаду. Происходит это потому, что государственно-управленческая стратегия исходит из ошибочных посылок, несовместимых с факторами успеха страны.

Как работает этот механизм неуспеха? Государство управляет десятками жизненно важных параметров развития. По мнению авторов шеститомной монографии «Национальная идея России», оно выбирает их прогнозирует их и управляет ими в количественном, а также полуколичественном и качественном) виде ${ }^{17}$.

Таким параметром (количественным) является, например, коэффициент монетизации экономики. Результаты управления этим параметром - изъятие из экономики России около 3 трлн. долл. денежных средств. Доля государственной собственности в структуре всей собственности страны уже ниже, чем в странах с рыночной экономикой. Доля оплаты труда в ВВП страны занижена в 2-2,5 раза. Доля госрасходов в ВВП страны ниже, чем в США. Доля инвестиций в ВВП в России в 2,5 раза ниже, чем в Китае. Прогрессия подоходного налога в России вообще отсутствует. Отно-

17 См.: Национальная идея России. - М., 2012. Т. 6 . - С. 4026. 
шение экспорта к импорту в России в 2-3 раза больше, чем необходимо по балансу материальных трансграничных переносов, что противоречит национальным интересам.

Таких количественных примеров очень много. Государство устанавливает полуколичественные параметры развития (например, степень политической свободы, которая в России характеризуется наличием партийных суррогатов, криминализованных лоббистских структур, отсутствием активно действующих профсоюзов), которые влияют на эффективность государственной власти. Степень реальной независимости СМИ также зависит от воли государства. В России они либо подчинены административному контролю, либо приватизированы и служат узкокорпоративным интересам, но принципиально не контролируются с точки зрения защиты нравственности населения страны.

Государство устанавливает качественные порядки, например, охраняя или нет (как в современной России) нравственность. То есть вводя или не вводя запреты на распространение в СМИ порнографии, сцен насилия и жестокости, асоциального поведения, управляя Интернетом или принципиально от этого самоустраняясь $(85 \%$ ресурсов в Интернете - безнравственны и просто криминальны с точки зрения незаконных и деструктивных призывов).

Bce, что перечислено (а это лишь малая часть), и есть потенциалы (или факторы-потенциалы) развития страны. Общество и государство могут управлять ими. Но каким именно образом - это вытекает из сделанного ими выбора. А делают выбор они, исходя из Основного закона страны и всего вытекающего из него законодательства. Таким образом, становится понятна взаимосвязь конституции страны и успеха ее развития. Конституция программирует развитие страны.

Факторы-потенциалы описывают основные системы страны, ее ценностный выбор, который формирует мировоззрение и мотивирует поведение и деятельность общества от внутрисемейных отношений до трудовых и ратных. Они описывают институты образования, воспитания, науки, здравоохранения, культуры, обороны, средств массовой коммуникации и др.

В самом концентрированном, исходном виде практически все факторы воплощаются в виде ключевых ценностей.

В научном макете новой Конституции России потому и должен быть реализован специальный институт «высших ценностей России», из которого вытекает все построение государства и его жизнеустройство.

Жизнеустройство требует конкретного выбора решений конституционного уровня, который и был сделан. Что это за выбор?
Это нравственность, это обязанности и ответственность человека и власти, наряду с правами, свободами и полномочиями. Это достоинство, права и свободы всех граждан, а не только богатых.

Это социальная и территориальная справедливость. Это истинное народное самоуправление. Это истинный государственный суверенитет. Это цивилизационная идентичность русской (российской) государственности как ключ к успеху.

Это принцип, что природные ресурсы принадлежат и служат всей стране и ее народу, а не тем, кто «подсуетился» во время узаконенного дележа национального достояния.

Это направленные на социальную справедливость принципы экономической деятельности, отношений собственности.

Вывод по первой части статьи. В постсоветский период российских реформ характеризуется тем, что на жизнеспособности страны экономика перестала сказываться. Обнаружен парадокс - экономика перестала быть фактором жизнеспособности страны! Полученный факт означает - состояние российской экономической модели является фактором жизнеспособности иных государств.

Если страна пока и выживает, то отнюдь не благодаря экономическому развитию. Ресурс ее выживания в настоящее время связан с вычерпыванием психологических резервов населения, его долготерпения, его неприхотливости, большой инерционностью системы и пока еще не полностью израсходованным потенциалом, накопленным в дореформенный советский период.

Полученный факт, состоящий в том, что экономика не работает на жизнеспособность страны, говорит о неустойчивости системы. При исчерпании накопленных ресурсов она обязательно рухнет, если не произойдет смены модели экономики страны

Выводы по второй части статьи. Экономические теории и экономические практики, реализуемые в России с девяносто первого года, не оставляют для страны никаких перспектив.

И заменой этим смертоносным теориям и практикам может служить только стратегия рывка - незамедлительного в условиях трагического отставания России, которая оказалась безоружной и голой перед лицом грозных - в том числе и военных - опасностей. Отсюда острая необходимость в прекращении либерального эксперимента в социально-экономической сфере и в разработке Концепции развития страны (стратегия рывка), а также в возрождении национального обществоведения. 
Выводы по третьей части статьи. В юридической науке России сформировалось два подхода развития правовой системы. Первый подход - это юриспруденция, обслуживающая феодально-олигархическую модель «экономики трубы», это юриспруденция шахраев, резников, кучерен, морщаковых, мезулиных и макаровых, именуемая «басманным» правосудием. Он (первый подход) предполагает совершенствование существующей правовой системы, апологетику существующего порядка (управляемого хаоса) и отражает содержание официальной государственно-правовой доктрины политического режима 1993 г. В целом содержание постсоветского законодательства носит колониально - сырьевой характер и не способно обеспечить в стране должный правопорядок.
Второй подход развития правовой системы предполагает проведения мероприятий национально-освободительного характера в социально-экономической сфере и преодоление либерально-пораженческого (официального) подхода в правоведении, а также разработку принципиально новой национальной правовой доктрины. Начало этому процессу положено авторами шеститомной монографии «Национальная идея России», в томе шестом монографии (глава 19) ими разработан научный макет новой Конституции и доктрина безопасности и развития России. На этой основе возможно принципиальное обновление законодательства - принятие новой Конституции и основных законодательных актов - Гражданского, Уголовного, Трудового, Налогового, Земельного и других кодексов.

\section{Библиографический список:}

1. Политология. Энциклопедический словарь / Общ. ред. и сост.: Ю.И. Аверьянов. — М. 1993.

2. Глазьев С.Ю. Родина в опасности. - М., 2009 .

3. Дойников И.В. Актуальные проблемы управления государственной собственностью// Вопросы правоведения. - 2010. - № 2,3.

4. Дойников И.В. Проблемы гражданского и предпринимательского права в Послании Президента РФ Федеральному Собранию России // Гражданское право. — 2010 - № 1.

5. Дойников И.В. Правовые проблемы экономической безопасности в концепции развития гражданского законодательства // Механизм экономико-правового обеспечения национальной безопасности: опыт, проблемы, перспективы. Т.2. — Краснодар. 2009.

6. Дойников И.В. Актуальные проблемы предпринимательского права. — М., 2012.

7. Дискин И. Хозяйственная система России: проблемы институционального генезиса // Общественные науки и современность. — 1998. - № 1.

8. Зыкова Т. Кто проспал кризис. Ученые диагностируют состояние российской экономики // Российская газета. 2009. - 8 декабря.

9. Зорькин В.Д. Конституция против криминала // Российская газета. Столичный выпуск. $-2010 .-10$ декабря.

10. Кара-Мурза С. Кризисное обществоведение. Часть первая. Курс лекций. - М., 2011.

11. Метелев С.Е. Национальная безопасность и приоритеты развития России: социально-экономические и правовые аспекты: монография. - М., 2006.

12. Нуриэль Рубини, Стивен Мим. Как я предсказал кризис. Экстренный курс подготовки к будущим потрясениям. - М., 2011.

13. Кричевский Н., Иноземцев В. Постпикалевская Россия: новая политэкономическая реальность // Известия. 2009. - 17 августа.

14. Кара-Мурза С. Кризисное обществоведение. Часть первая. Курс лекций. — М., 2011.

15. Мамутов В.К. По поводу одной статьи Е.А. Суханова // Предпринимательское право. — 2011. — № 2.

16. Путин В.В. «Россия: национальный вопрос» // Независимая газета. - 2012. - 23 января.

17. Петраков Н. С чем пожалуем // Литературная газета. - 2010. — № 6-7.

18. Примаков Е.М. Цены можно снизить! // Аргументы и факты. - 2010. — № 2.

19. Суханов Е.А. Перспективы корпоративного права // Закон. - 2006. - № 9.

20. Шляпентох В. Современная Россия как феодальное общество. - М., 2008. 


\section{References (transliteration):}

1. Politologiya. Entsiklopedicheskiy slovar'/ Obshch. red. i sost.: Yu.I. Aver'yanov. — M. 1993.

2. Glaz'ev S.Yu. Rodina v opasnosti. - M., 2009.

3. Doynikov I.V. Aktual'nye problemy upravleniya gosudarstvennoy sobstvennost'yu// Voprosy pravovedeniya. 2010. — № 2,3.

4. Doynikov I. V. Problemy grazhdanskogo i predprinimatel'skogo prava v Poslanii Prezidenta RF Federal'nomu Sobraniyu Rossii // Grazhdanskoe pravo. — 2010 - № 1.

5. Doynikov I.V. Pravovye problemy ekonomicheskoy bezopasnosti v kontseptsii razvitiya grazhdanskogo zakonodatel'stva // Mekhanizm ekonomiko-pravovogo obespecheniya natsional'noy bezopasnosti: opyt, problemy, perspektivy. T. 2. - Krasnodar. 2009.

6. Doynikov I.V. Aktual'nye problemy predprinimatel'skogo prava. - M., 2012.

7. Diskin I. Khozyaystvennaya sistema Rossii: problemy institutsional'nogo genezisa // Obshchestvennye nauki i sovremennost'. - 1998. - № 1.

8. Zykova T. Kto prospal krizis. Uchenye diagnostiruyut sostoyanie rossiyskoy ekonomiki // Rossiyskaya gazeta. 2009. - 8 dekabrya.

9. Zor'kin V.D. Konstitutsiya protiv kriminala // Rossiyskaya gazeta. Stolichnyy vypusk. $-2010 .-10$ dekabrya.

10. Kara-Murza S. Krizisnoe obshchestvovedenie. Chast' pervaya. Kurs lektsiy. - M., 2011.

11. Metelev S.E. Natsional'naya bezopasnost' i prioritety razvitiya Rossii: sotsial'no-ekonomicheskie i pravovye aspekty: monografiya. - M., 2006.

12. Nuriel' Rubini, Stiven Mim. Kak ya predskazal krizis. Ekstrennyy kurs podgotovki k budushchim potryaseniyam. M., 2011.

13. Krichevskiy N., Inozemtsev V. Postpikalevskaya Rossiya: novaya politekonomicheskaya real'nost' // Izvestiya. 2009. - 17 avgusta.

14. Kara-Murza S. Krizisnoe obshchestvovedenie. Chast' pervaya. Kurs lektsiy. — M., 2011.

15. Mamutov V.K. Po povodu odnoy stat'i E.A.Sukhanova // Predprinimatel'skoe pravo. — 2011. — № 2.

16. Putin V.V. «Rossiya: natsional'nyy vopros» // Nezavisimaya gazeta. — 2012. — 23 yanvarya.

17. Petrakov N. S chem pozhaluem // Literaturnaya gazeta. — 2010. — № 6-7.

18. Primakov E.M. Tseny mozhno snizit'! // Argumenty i fakty. — 2010. — № 2.

19. Sukhanov E.A. Perspektivy korporativnogo prava // Zakon. - 2006. - № 9.

20. Shlyapentokh V. Sovremennaya Rossiya kak feodal'noe obshchestvo. - M. 2008. 